\title{
Perancangan Karakter Pendukung Animasi Serial "Little Bird" dengan Mengadaptasi Satwa Burung Endemik Indonesia
}

\author{
Muhammad Harya Prayogi, dan Sayatman \\ Departemen Desain Produk Industri, Fakultas Desain, Arsitektur dan Perencanaan \\ Institut Teknologi Sepuluh Nopember (ITS) \\ e-mail: sayatasik@gmail.com
}

\begin{abstract}
Abstrak-Animasi merupakan salahsatu subsektor industri kreatif dalam peta Ekonomi Keratif di Indonesia. Rencana pemerintah dalam menitikberatkan pengembangan animasi periode 2015-2019 adalah melalui pengembangan Intellectual Property (IP) yang memanfaatkan sumber kekayaan alam dan budaya nusantara sebagai modal dasar pengembangan termasuk hak paten model karakter dari animasi tersebut. Hal itu merupakan peluang sekaligus tantangan untuk para animator dan kreator konten Indonesia dalam menciptakan karya-karya animasi dan konten yang lebih bermutu. Perancangan ini bertujuan menciptakan karakter pendukung untuk serial animasi 3D "Little Bird" yang dikembangkan dengan mengadaptasi karakter satwa burung endemic Indonesia. Penggalian karakter ini bertujuan untuk memperkenalkan keanekaragaman burung endemik khas Indonesia memang belum pernah ada, sehingga dapat menjadi peluang yang baik untuk diangkat sebagai salah satu unsur identitas kekayaan alam yang dimiliki oleh negeri ini. Rancangan karakter ini kemudian diaplikasikan ke dalam sifat dan kepribadian semua karakter yang khas. Wujud akhir dari perancangan ini adalah 5 karakter pendukung untuk serial animasi Litle Bird, diantaranya 2 karakter pendamping dan 3 karakter insidental dengan berbagai ekspresi dan pose.
\end{abstract}

Kata Kunci-Animasi Serial, Slapstick, Intellectual Property, Burung, Karakter Pendukung

\section{PENDAHULUAN}

$\mathrm{P}$ ERIODE tahun 2015-2019 pemerintah menargetkan pembangunan ekonomi kreatif di Indonesia secara intensif, salah satunya adalah pembentukan Intellectual Property (IP) di sektor industri kreatif. Intellectual Property adalah kekayaan yang dihasilkan dari proses berfikir manusia untuk menciptakan produk yang memiliki nilai jual dan telah diakui oleh negara berdasarkan peraturan perundang-undangan yang berlaku. Industri kreatif merupakan industri yang memiliki pengaruh cukup besar dalam memajukan perekonomian bangsa, karena memiliki nilai jual yang sangat tinggi di pasar internasional dan mampu menyerap tenaga kerja yang sangat banyak. Salah satu bidang industri kreatif yang sedang berkembang adalah animasi.

Penggabungan konsep perundungan dan pengenalan burung endemik menjadi konsep cerita dengan judul Little Bird. Animasi ini bercerita tentang hidup seekor burung kecil, remeh dan cerdik yang berinteraksi dengan burung lainnya dalam dunia fantasi di atas awan. Konsep Cerita tersebut dibuat ringan, mengandung unsur komedi, tidak membawa unsur kekerasan yang berlebihan, dan mudah untuk dinikmati oleh semua umur terutama usia 4-9 tahun. Berbagai macam bentuk perundungan digambarkan di dalam ceritanya.

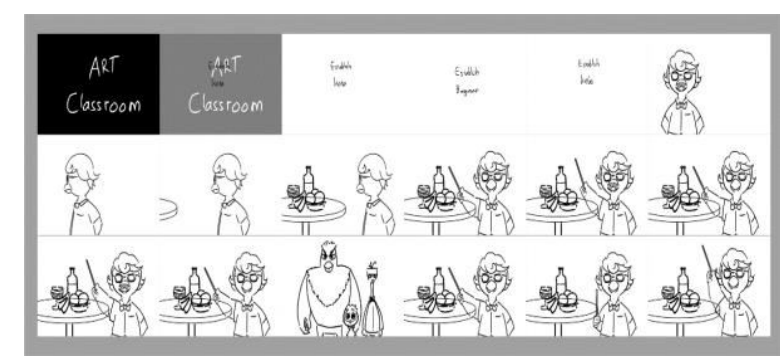

Gambar 1. Contoh screenshot storyboard Little Bird, Art Classroom.

Untuk itu, dibutuhkan karakter yang tepat untuk memerankan tokoh dalam cerita. Animasi Disney selalu menciptakan karakter yang mampu membuat penonton sangat mempercayai karakter-karakternya [1]. Pembagian karakter dalam perancangan ini dibagi menjadi dua kelompok, yaitu karakter utama dan karakter pendukung. Pengaruh karakter pendukung sebagian besar berperan sebagai teman atau rekan yang menunjukkan sikap yang positif.sedangkan karakter insidental hanya sebagai pemeran figuran yang memenuhi latar tempat disesuaikan dengan suasana dan keadaan di dalam cerita. Khusus untuk karakter utama dibahas oleh penulis yang berbeda.

\section{A. Identifikasi Masalah} berikut:

Permasalahan dalam penelitian ini adalah sebagai

1. Animasi merupakan bagian dari subsektor film, video, dan fotografi yang kemudian difokuskan harus dikembangakan secara khusus sebagai kelompok industri kreatif pada periode 2015-2019, karena potensinya sangat berpengaruh terhadap pengembangan IP serta memiliki dampak sosial dan budaya yang luas bagi Indonesia.

2. Film animasi Little Bird membutuhkan karakter pendukung yang representatif dan memiliki pengaruh kuat terhadap karakter utama. Karena karakter pendukung merupakan salah satu elemen penting dalam animasi sebagai pembawa cerita.

3. Film animasi Little Bird membutuhkan karakter yang harus diadaptasi dari objek nyata kedalam gaya stylized, menonjolkan keanekaragaman jenis burung khas Indonesia; secara visual dan menentukan pembawaan karakter yang dapat disukai anak-anak masa kini.

\section{B. Batasan Masalah}

Penelitian ini fokus pada perancangan karakter pendukung untuk film Little Bird yang memiliki batasan sebagai berikut: 
1. Proses perancangan karakter mulai dari konsep sketsa, hingga menjadi bentuk 3D.

2. Fokus perancangan karakter pendukung menitikberatkan pada konsep visual 6 tokoh utama dalam cerita "Little Bird".

3. Desain karakter akan di eksekusi masing-masing dalam bentuk render 3D beserta pose, gerakan, maupun ekspresi.

4. Penulis membatasi perancangan ini dalam hal pembuatan sketsa dan concept art karakter pendukung. Sedangkan desain karakter utama, dan environment dari serial ini akan dibahas dalam laporan tugas akhir perancangan dari penulis yang berbeda.

\section{Rumusan Masalah}

Bagaimana merancang konsep karakter pendukung dengan mengadaptasi bentuk satwa burung Indonesia bergaya gambar stylized sebagai elemen visual pendukung konten animasi serial "Little Bird".

\section{Tujuan Penelitian}

1. Memperkuat personality masing-masing karakter melalui studi archetype

2. Menemukan bentuk karakter yang sesuai dengan sifat dan peranan masing-masing karakter dalam cerita film animasi Little Bird.

3. Menemukan struktur dan proporsi tubuh yang disesuaikan dengan konsep karakter dari gradasi morfologi burung dan manusia diterapkan dalam desain karakter animasi Little Bird.

\section{E. Manfaat Penelitian}

Hasil penelitian ini diharapkan memperoleh manfaat baik secara umum maupun khusus.

1. Manfaatnya secara umum, Hasil penilitian ini diharapkan dapat memberikan manfaat sebagai sumbangan pemikiran bagi dunia desain dan industri animasi.

2. Bagi pihak akademis, berlaku sebagai kajian proses pembuatan film animasi terutama dari segi perancangan karakter. Sebagai studi referensi tentang kekayaan ragam satwa burung Indonesia.

3. Bagi Desainer, bisa menjadi referensi style karakter 3D dalam membawakan konten lokal dengan tema cerita animasi Little Bird.

4. Dan untuk stakeholder, sebagai contoh referensi ide untuk pengembangan aset animasi dan konsep IP baru perusahaan.

\section{TINJAUAN PUSTAKA}

\section{A. Landasan Teori Pembuatan Karakter Pendukung}

Di dalam bukunya yang berjudul "Creative Character Design", Bryan Tillman mengatakan "Character is a he". Di dalam bahasa Indonesia artinya, "Karakter adalah dia". Dari ucapan singkat Bryan Tillman tersebut, dapat ditarik kesimpulan bahwa karakter merupakan sesuatu yang memiliki peran untuk membawakan cerita. Layaknya manusia, "Dia" memiliki sifat, latar belakang hidupnya, kepribadian, kebiasaan, keinginan, serta peranan yang dapat membangun cerita dalam sebuah film. Karakter dalam film animasi bisa berbentuk manusia, hewan, tumbuhan atau bahkan benda mati sekalipun untuk memerankan tokoh dalam alur cerita. Tanpa kehadiran karakter, sebuah cerita tidak akan pernah muncul untuk dipentaskan dalam sebuah film.

\section{METODOLOGI DESAIN}

\section{A. Metode Penelitian}

Metode penelitian ini dilakukan dalam 2 tahap. Tahap pertama riset data konten karakter. 2 Tahap perancangan karakter.

Tahap riset data dilakukan melalui observasi lapangan tentang satwa burung endemic, studi pustaka dan literature dan wawancara kepada pakar animasi.

Tahap perancangan karakter pendukung animasi Litle Bird, meliputi tahapan-tahapan sbb:

1. Mempelajari Pengkarakteran

Setelah script cerita tersusun, desainer karakter membuat list karakter apa saja yang akan dibuat dilanjutkan dengan tahap perancangan yang berurut. Pengkarakteran seperti deskripsi singkat, biodata, fitur yang membedakannya, dan strata sosial masing-masing karakter ditentukan.

2. Menemukan Archetype dan Bentuk Karakter

Menurut bahasa, kata archetype berasal dari bahasa latin yaitu archetypum yang berarti "bentukan pertama" . Menurut Bryan Tillman, arketipe mewakili-ciri-ciri kepribadian dan identifikasi karakter. Arketipe adalah bawaan, prototipe universal untuk ide-ide dan dapat digunakan untuk menafsirkan pengamatan [2]. Menurut Jung ada hubungan antara psikologi dan fisik.

3. Referensi (Moodboard)

Setelah mempelajari archetype dan bentuk karakter, tahap selanjutnya adalah mengumpulkan referensi untuk masing-masing karakter. Referensi berguna untuk mempermudah desainer dalam mengonsep. Semakin banyak dan bagus referensi yang dikumpulkan, akan semakin mempermudah desainer dalam mendesain.

4. Gaya Gambar

Ada berbagai macam style karakter 3D, tetapi dalam perancangan penulis menggunakan gaya gambar stylized. Stylized atau stilasi adalah desain karakter yang memiliki proporsi mendekati aslinya dengan menonjolkan garis dan warna untuk mencapai tampilan yang unik. Gaya gambar ini dipilih karena dalam eksekusinya penulis menggunakan teknologi motion capture yang merekam gerakan manusia asli ke dalam bentuk 3D. Gerakan motion capture akan disesuaikan dengan model yang hampir mendekati proporsi manusia atau humanoid.

5. Basic Shape dan Solid Drawing

Bentuk merupakan hal yang dapat kita gunakan untuk mendefinisikan sesuatu dan fungsi dari bentuknya. sebagai contoh bentuk persegi dapat dijadikan sebagai kotak kardus. Ketika orang akan membuat sesuatu yang memiliki fungsi untuk mengangkut barang seperti kotak kardus, dia akan memilih bentuk persegi bukan lingkaran.

Adapun Solid Drawing merupakan penggambaran bentuk yang terlihat lebih dari sekedar silhouette pada sebuah objek yang tidak hanya berfungsi sebagai identifikasi karakter tetapi juga mengenali pose yang dilakukan oleh karakter tersebut.

6. Sketsa

Setelah Ditentukan basic shape dan solid drawing, step selanjutnya adalah membuat sketsa dari proses 
sebelumnya. Dalam step ini ditentukan detail wajah, tubuh, dan aksesoris yang dikenakan oleh karakter yang
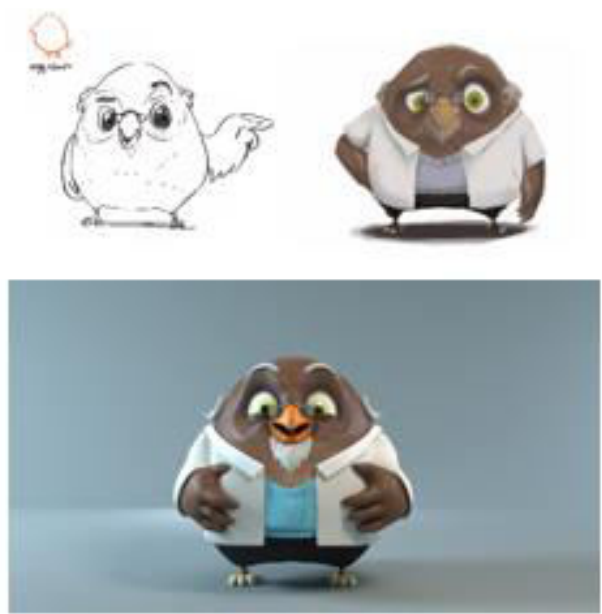

Gambar 2. Sketsa, Artwork, dan model 3D karakter Prof. Oll.

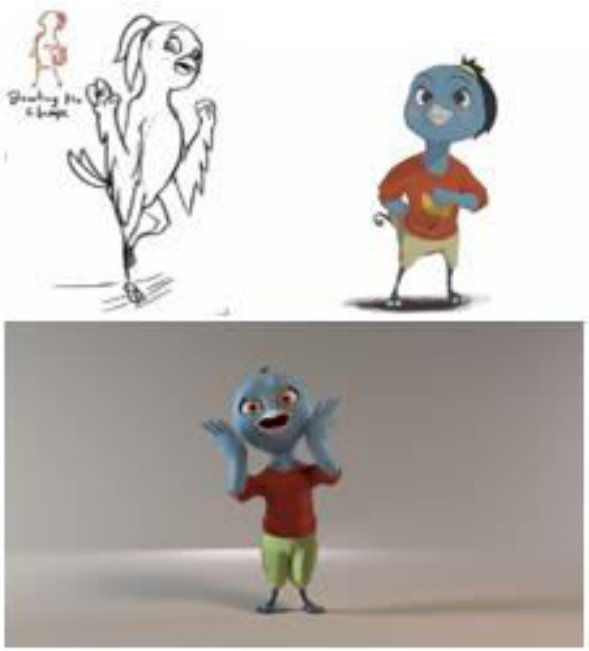

Gambar 3. Sketsa, Artwork, dan model 3D karakter Blu

\section{Warna}

Warna sangat berpengaruh terhadap karakter. Dengan warna, sebuah karakter dapat terlihat personality, ras, jabatan dan lain sebagainya. Karena yang diangkat penulis adalah film yang berhubungan dengan dunia fantasi maka jenis warna yang digunakan sesuai dengan beberapa referensi yang ada dengan sedikit perubahan tentunya agar semakin menarik.

8. Studi Archetype dan Bentuk Karakter

Hal inilah yang membuat studi archetype ini penting sekali dilakukan dan hanya untuk karakter yang dibutuhkan dalam perancangan ini saja.

9. Bentuk Pakaian

Setelah diteliti archetype dan bentuk karakter, langkah selanjutnya menganalisa bentuk pakaian yang ada pada karakter tertentu sesuai dengan status sosial dari tiap karakter. Hal ini penting untuk dilakukan, karena pakaian atau aksesoris merupakan penanda dan pembeda antara karakter satu dengan yang lainnya.

\section{IV.STUDI DAN ANALISIS}

Beberapa poin dibawah ini adalah hasil studi dan analasis yang telah dilakukan dalam perancangan karakter pendukung serial animasi Little Bird. disesuaikan dengan studi yang telah dipelajari sebelumnya.
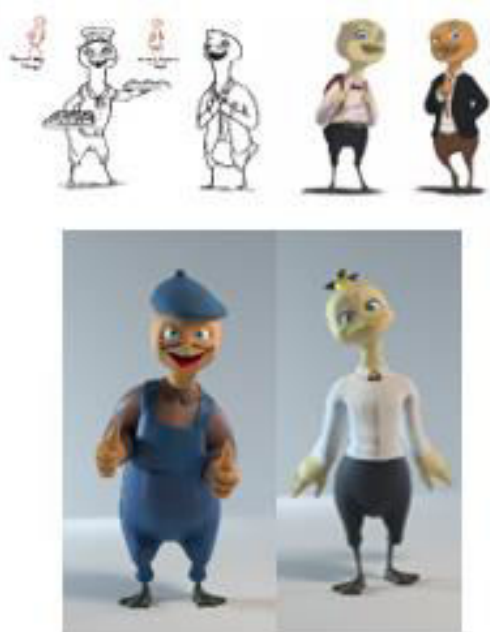

Gambar 4. Sketsa, Artwork, dan model 3D karakter Trader.

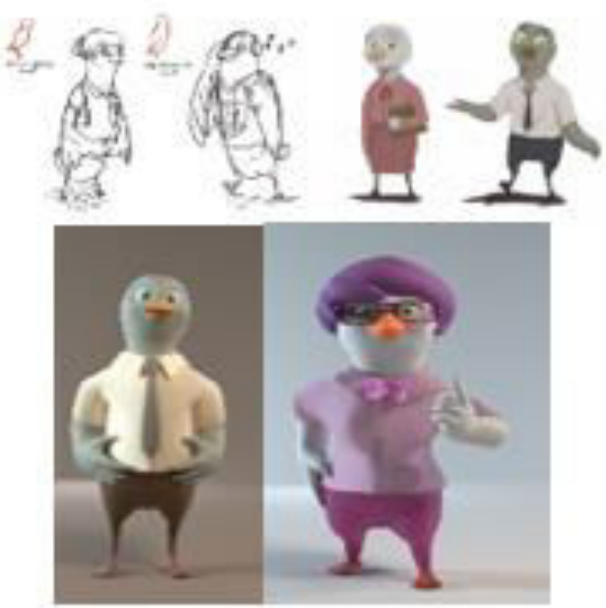

Gambar 5. Sketsa, Artwork, dan model 3D karakter Worker

Dari beberapa hasil pelaksanaan riset lapangan, telah terkumpul dan terbentuk sebuah kesimpulan permasalahan yang diprioritaskan seperti:

1. Burung endemik yang cukup dikenal dan unik memiliki jumlah populasi sedikit dan tepat untuk dijadikan sebagai objek adaptasi karakter dengan peran tertentu.

2. Animasi di Indonesia perlu mengangkat konten lokal tetapi dengan kualitas Internasional

3. Untuk anak usia dini percakapan lebih cocok dengan animasi slapstick.

4. Konsep karakter animasi yang mengangkat burung endemik khas Indonesia memang belum pernah ada dan itu dapat menjadi peluang yang baik untuk diangkat sebagai salah satu unsur kekayaan alam yang dimiliki oleh negeri ini.

5. Anak-anak lebih menyukai karakter yang unik dan terlihat lucu bagi mereka (memorable)

6. Hasil Obeservasi: Semua varietas atau jenis burung di Taman Eco Green Park Malang ini memiliki ciri khas dan keunikan yang dapat diambil sebagai data dengan aspek kualitas untuk menjadi contoh pengadaptasian karakter animasi.

7. Hasil Wawancara: Dengan adanya wawancara ini semakin didapat informasi mengenai pengembangan IP yang perlu diperhatikan dari segi konsep yang diutamakan. Lebih banyak mengetahui perkembangan 
animasi lokal yang mulai banyak menampilkan karyanya di layar televisi lokal maupun saluran pribadi via Internet.

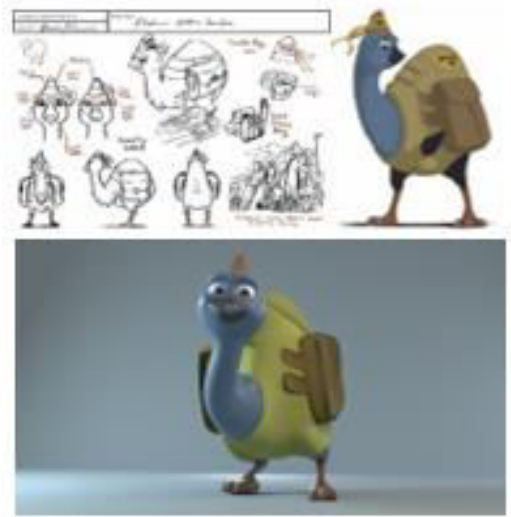

Gambar 6. Sketsa, Artwork, dan model 3D karakter Carrier.

8. Riset Eksperimental: Sketsa yang lebih banyak dipilih menjadi acuan desain karakter untuk lebih dikembangkan dalam penerapannya pada objek 3D. Ini menjadi bukti bahwa karakter yang lebih banyak disukai oleh anak memberikan contoh bahwa pasar mempunyai arus yang tidak dapat baca.

9. Metode FGD Menghasilkan sejumlah kesimpulan yang menyinggung penciptaan karakter beserta kurang dan lebihnya, perannya dalam cerita yang harus lebih kuat, dan berkesinambungan antar satu karakter dengan karakter lainnya dimana harus memiliki pola pertemuan antar karakter.

\section{HASIL DESAIN}

\section{A. Gambaran Umum}

Indonesia kaya akan berbagai keanekaragaman hayatinya. Negara kepulauan ini juga menyimpan banyak potensi yang dapat diangkat untuk menjadi sebuah kisah maupun cerita dibalik keindahan alamnya.

Dari segi industri, Indonesia memiliki peluang yang bagus. Hal ini terbukti dari tayangan televisi berjenis animasi, Animasi lokal terus berusaha menempati rating yang cukup bersaing dengan judul animasi luar.

Jika melihat pasar lokal, khususnya stasiun TV lokal masih belum mampu menyerap produksi dalam negeri. Penghargaan secara materi yang belum berimbang dari biaya produksi menjadi andil bagi rumah produksi animasi tidak begitu berani menciptakan produk untuk pasar lokal.

Oleh karena itu, penulis dan tim dibawah naungan stake holder Hompimpa Animation memutuskan untuk menciptakan sekali lagi sebuah IP yang dikonsep lebih siap terhadap pasaran animasi serial lokal maupun global dengan ide Little Bird ini yang nantinya semakin dikembangkan hingga kancah perindustrian. Didukung dengan teknologi motion capture untuk meminimalisir kebutuhan SDM, mempercepat waktu dan memangkas biaya produksi.

\section{B. Cerita (Episode Pilot)}

Dalam perancangan kali ini, penulis bersama tim telah menyusun cerita yang disepakati dari sejumlah alternatif premis dan logline hingga memunculkan satu ide cerita untuk dieksekusi Bersama dengan memasukkan peran karakter pendukung dan utama. (Gambar 1)

\section{Desain Karakter}

Dalam perancangan kali ini, penulis bertugas memenuhi desain semua karakter yang dibutuhkan di dalam cerita Little Bird yang dibuat oleh tim penulis. Berikut ini adalah list dari karakter yang harus didesain oleh penulis hingga menjadi objek 3D yang siap memasuki tahap produksi.

\section{Professor Oll}

Professor Oll merupakan tokoh pendamping, yang berperan sebagai salah satu orang yang membantu Bli untuk memenuhi semua kebutuhan yang diperlukan karakter utama. Perannya tidak secara langsung mendukung Bli dalam membantunya mencegah pembulian. (Gambar 2)

2. Blu

Sosok gadis yang ramah terhadap semua orang, baik hati, dan memiliki aura yang selalu dipandang positif. Berbanding jauh dengan karakter utama protagonis, Bli yang banyak mendatangkan hasutan untuk membuli dirinya. (Gambar 3)

\section{Duck Citizen (Trader)}

Adalah masyarakat umum yang berasal dari bangsa bebek, dan menetap lama di kota Differ-City dengan profesi umumnya seperti saudagar, penjaga toko, bussinessman dan lainnya yang intinya tidak jauh dari berdagang. (Gambar 4)

\section{Pigeon Citizen (Worker)}

Adalah masyarakat umum yang berasal dari bangsa merpati, dan menetap lama di kota Differ-City dengan berbagai macam profesi seperti pekerja kantoran, kontraktor, pelayanan masyarakat dan lainnya yang intinya tidak jauh dari bekerja di perkantoran. (Gambar 5)

5. Carrier

Adalah masyarakat yang mengkhususkan diri mereka untuk bekerja membawa barang dan hampir tidak memiliki tujuan hidup lain. (Gambar 6)

\section{KESIMPULAN DAN SARAN}

\section{A. Kesimpulan}

1. Karakter pendukung, terutama bagi karakter pendamping memiliki peran pada awal episode untuk mengenalkan bahwa dibalik kasus perundungan, setidaknya ada karakter support dalam membantu mengantarkan pada solusi dalam cerita yang disampaikan.

2. Selama merancang karakter dalam bentuk 3D, didapati sejumlah kendala dalam menyusun rigging atau tulang untuk membantu objek 3D statis tersebut agar bergerak.

3. Adapun pengurangan karakter pendamping yang dianggap kurang berperan penting bagi konsep dalam serial ini yang masih belum memilliki visi misi yang jelas.

4. Perubahan bentuk dan morfologi yang harus lebih berkenaan dengan karakteristiknya juga merupakan upaya yang harus diperhatikan selama proses perancangan karakter mulai dari sketsa kasar hingga bentuk final 3D-nya.

\section{B. Saran}

Hal yang perlu lebih diperhatikan dalam perancangan karakter pendukung untuk melengkapi serial animasi Little Bird adalah perlunya mengoptimalkan peran pada masingmasing karakter agar mereka diciptakan begitu berkesan ketika berperan dalam ceritanya. Diupayakan agar karakter juga dikembangkan lebih berpengaruh kepada alur cerita. 


\section{DAFTAR PUSTAKA}

[1] F. Thomas and O. Johnston, Illusion of Life. Walt Disney Productions, 1981.
[2] C. G. Boeree, "Boeree, C. George," 2006. [Online]. Available: https//webspace.ship.edu/cgboer/jung.html. 